\title{
The Enlightenment of Cultural Identity in Coetzee's Diaspora Writing on the Integration of New Citizens in China
}

\author{
Wei Ding*, Dan Gao \\ Email address: \\ 520xue0308@163.com (Wei Ding), 171716704@qq.com (Dan Gao) \\ ${ }^{*}$ Corresponding author
}

English Department of Humanities and Social Sciences, Heilongjiang Bayi Agricultural University, Daqing, China

\section{To cite this article:}

Wei Ding, Dan Gao. The Enlightenment of Cultural Identity in Coetzee's Diaspora Writing on the Integration of New Citizens in China. Humanities and Social Sciences. Vol. 8, No. 1, 2020, pp. 30-34. doi: 10.11648/j.hss.20200801.15

Received: January 8, 2020; Accepted: February 14, 2020; Published: February 25, 2020

\begin{abstract}
As a diaspora writer, Coetzee has a deep understanding of the identity crisis, and his works reflect the profound thinking on this issue and the positive exploration of the solution to the problem. This paper starts with the narrative strategy of Coetzee's works and analyzes that diaspora subject constantly encounters the identity crisis in the environment and through the expression of discourse constructs a new identity. This study examined the issue of identity of new citizens in the fast development of urbanization in China, which became an obstacle for them to get integrated to the city. After the analysis of questionnaire among new citizens, this study found that language use functions as a major element to influence their identity. Through the analysis of discourse mode and identity issues of Coetzee's novels, the paper showed that the concept of respecting the individual, equality and harmony to get the identity adaptation of the new citizen is conducive to promoting the integration of different regional cultures, enhancing the understanding between people, and alleviating the personal pressure and social contradictions caused by the difficulties of integration. Thus the study can provide a feasible solution for the immigrant integration problem faced by new citizens in the process of urbanization in China.
\end{abstract}

Keywords: Diaspora Writing, Coetzee, Cultural Identity

\section{Introduction}

Cultural identity refers to an affirmative cultural value judgment, which is an identification of certain social values and lifestyles. The inability to carry out cultural identity will lead to the loss of one's own spiritual foundation, and therefore people will be in a rootless state of culture. This state make people lose the peace of mind and sense of security. To be diasporic or exiled is, in Said's terms, to comprehend fully the condition of 'not-belonging'. [1] According to this theory, the analysis of the status quo of the identity crisis in the process of urban integration and the research and analysis of the "aphasia" state of the new citizens have social significance.

Urbanization is a fundamental change in the form of human society and the way people live. It refers not only to the natural evolution of traditional agricultural society to modern urban society, but also to a great transformation in individual lifestyle and cultural psychology. The impact of urbanization on individuals is clearly reflected in urban identity. Due to its own complexity and particularity, China's urbanization has caused many obstacles for the integration of migrant workers into the urban living system, which has caused the new citizens to face identity problems. Language urbanization is not only part of cultural and spiritual urbanization, but also a very important matter. Language itself has a strong characteristic of humanism. [2] Both urban dialect and regional dialect are loaded with many cultural connotations, which is an indispensable part of the process of cultural urbanization. At the same time, as the most powerful communication tool, language (including text) will also play a strong role in the process of urbanization. Communication between people depends upon language. Understanding is the premise, while being willing to speak and listen to each other is the process of communication. Only in this way can communication be realized, mutual acceptance be achieved, and real change of citizen identity be realized for new citizens. The shaping of the discourse of others and the modern transformation of values constitute important factors influencing the identification dilemma of migrant workers in 
the process of urbanization in China. Based on this, the analysis of the way of constructing identity through Coetzee's choice of discourse mode can provide new citizens with reference to integrate into urban life through speech adaptation. Therefore, the issue of language urbanization is also a practical topic worthy of deep thinking and research.

With the development of the economy, the mobility of residents in urban and rural areas, regions and countries has increased, and the phenomenon of diaspora has become more and more prominent. The issue of immigration has increasingly become an important topic in cultural and social studies. Promoting urbanization is China's current development strategy. China's urbanization rate has reached $55 \%$ in 2014 from $36 \%$ in 2000, and will reach $70 \%$ in 2050 . However, after the new citizens moved from the countryside to the city, they could not integrate into the cities very well. Their relationship with the urban citizens was relatively estranged and formed a kind of exclusionary identity. At present, the study on the identity of the new citizens in China is mainly concentrated on the social welfare system, and is rarely oriented to know how the new citizens adapt to the language, to use the right of speech, and build a sense of belonging. As a diaspora writer, Coetzee's works reflect the profound thinking of identity and the active exploration of solutions to problems. The analysis of discourse mode and identity of Coetzee's novels can provide a feasible solution for the immigrant integration problems faced by new citizens in the process of urbanization in China.

\section{The Appearance of Diaspora}

On the level of experience, the phenomenon of "diaspora" is the immigration problem -- no matter forced, passive dispersion or active external migration, it has historical origins and many manifestations all over the world. If we insist on the cultural identity of the home country, the immigrants will always be the "other" in the new immigration place. If we adopt the attitude of identifying with the new residence place, we will assimilate and lose the inherent cultural characteristics. If we alienate our own cultural tradition and refuse to identify with the culture of the new immigration place, we will inevitably enter the rootless state. [3] In academic research, the objects of dispersion research can be divided into broad and narrow sense. In a narrow sense, it refers to the historical study of the judaeo-hebrew period before Christ, according to which the cultural study of related ethnic groups (such as Jews) is expanded. However, the current use is the universal meaning of the concept of dispersion, which refers to the product associated with the ongoing phenomenon of transnational migration. More broadly, it includes "internal migration", that is, population migration, regional relations and social changes within a country. In its broadest sense, it includes the changes in the spiritual field accompanied by people's migration, such as cultural philosophy, understanding of literature and art, thus giving rise to such views as diaspora culture, diaspora literature (diaspora writers) and diaspora aesthetics.

In recent years, more and more researches on "new citizens" begin to point to "migrant workers", "landless farmers" or "migrant farmers" and other rural migrants. [4] In today's life, even common residents can feel the social effects caused by the phenomenon of dispersion. For example, the emergence of transnational and trans-regional companies makes managers often carry out transnational and trans-regional business activities. All kinds of travel, study abroad and multinational inter-district family gathering, make most of the city residential demand can not be judged by the number of permanent residents. The change of the demand, and other variables (such as the basic facilities, selective schools and cultural facilities), have influenced the prices in different cities and regions, house price fluctuations and the change of the social environment. These are the signs of China's recent changes in life, but the relevant specific research is very scarce, or this research usually belongs to the category of "national economy", and the lack of consciousness combined with diaspora research.

\section{The Features of Coetzee's Diaspora Literature}

The background, family, society and history of John Maxwell Coetzee's growth had profound influence and enlightenment on the creation of his novels. Although Coetzee was born in South Africa, he is a descendant of the Dutch. Due to the Dutch and German lineage of his parents, he was already divided into colonial positions by history. $\mathrm{He}$ was educated in the UK from an early age and was influenced by British culture. When he was a child, Coetzee longed for everything in the UK in his heart. In the 1860s, Coetzee immigrated to the UK, and after that he studied literature in the United States and started his own literary writing. However, Coetzee chose Australia as the final settlement. It is the geography of Australia that has made its mark on Coetzee, not its history (or rather, it is the idea of Australian geography that has influenced him rather than its particularity) whereas in South Africa, as the essays on land and landscape of White Writing reveal, geography and history are, in a certain sense, indistinguishable. [5]

Foucault believes that discourse is a statement system through which society establishes a power relationship between subject and object. [6] From the perspective of language usage, English was regarded as the first frequently used language by Coetzee, he also was proficient in other languages and still wrote and explained his opinions freely in English. However, the English used by Coetzee has become a different language from the past and the language became a tool which he can re-expresses meanings. Coetzee's writing is a kind of boundary writing, breaking the limitations of English syntax and grammar, and discovering a new expression system. From the perspective of identity, diaspora writers tend to identify themselves in multiculturalism, thus emphasizing the recognition of differences and different 
regional cultures. Due to the influence of the two cultures, he had a sense of alienation from the United Kingdom and South Africa. He wanted to integrate into a certain cultural system, but he found himself only in a subjectively created marginalized external world. He was surrounded by a rootless state. The main characters in his works were full of nostalgic psychology, and his heart was full of loneliness and dislocation. In terms of cultural identity, the diaspora writers have the characteristics of cultural hodgepodge, and the creation of their literary works is unique. Coetzee himself has foregrounded immigrant cultural identities in Slow Man (2005), whereas the historical African diaspora and its continuation into the present-day dispersal of Africans into diaspora communities around the world. [7] Coetzee pays special attention to the multiplicity of British identity and multicultural context, revealing the mixed and uncertain aspects of regionality and identity. This new literary creation model is the result of collisions between different cultural regions. And it is seen as a new type of cross-cultural creation which was caused by colonization in the areas consisted of different cultures. Further, as a modernist writer, Coetzee is influenced by some important modernists, such as Eliot and Pound who also have the dilemma to comment the political event through poetry. Similar to Pericles Lewis, Coetzee may suffer "a consciousness of living in a world that was utterly different from that of their parents, whether because of new religious and scientific beliefs, of industrialization, of changing attitudes to sex and gender, or of transformative political event." [8] Coetzee's works also contain fable narratives, which not only reflect the colonial oppression suffered by the natives in his country, but also express his sympathy for the marginalized individual and resistance to the colonists. In the novel Waiting for the Barbarians, the author did not set a specific time and place, so the story may occur in any age and country. It indicates that "it is still sometimes difficult to distinguish the diasporic subject from the exile, the diasporised community from its é migr é counterpart." [9] Another feature of his works is the anti-traditional narrative poetry. In the novel In the Heart of the Country, Magnum's record of South Africa in his diary subverted the idyllic writing tradition of Africa in the 18th century English literature. Similarly, the novel Foe is the imitation of 18th-century British tramp novels, which has played a subversive role in traditional literature.

As a diaspora writer, the narrative features in Coetzee's works above showed a strong sense of identity. The multi-cultural identity of diaspora writers enables them to get rid of the limitation of single cultural identity, shuttle between two or more cultures, and construct their own cultural experience from a broader perspective. [10] When retaining their own cultural traditions, they also integrated the culture of other regions and different nationalities in the collision of different cultures. In his works, he showed deep concern for the common destiny of humanity and also demonstrated his willingness to explore human civilization.

\section{The Enlightenment of Coetzee's Diaspora Writing to the Social Integration of the New Citizens}

Language can maintain the common values of society. As the carrier of culture, the emergence, development and intergenerational communication of language are closely connected with culture. [11] By analyzing the way Coetzee constructs his identity through the choice of discourse patterns, we can see that Coetzee has deep sympathy for the individuals and calls for respect for them. Coetzee's holds an ideal world in his heart where all life and non-life live in a harmony. He considered that human beings are equal beings with all objects in this vast universe. To appreciate and respect for all beings is the best way to reach harmony. Speaking a language is a conscious acceptance of a world, a culture. [12] In Shame, when Lewry saw two sheep waiting to be slaughtered, he wanted to buy them from Petrus, and he knew that "it doesn't make much sense. Petrus will buy two more sheep with money. "What is the point of such salvation? Which life has no meaning? Coetzee has pointed that we have to respect the life of each individual, and should not ignore the individual in the group. Coetzee's individual consciousness originated from his own experience and carry out from himself to other people, from other people to other life forms. This is the greatest respect for the other individual, Coetzee not only goes beyond the ego, but also beyond the views of anthropocentrism and even life-centred. In Coetzee's works, we can see that he shows great respect for the inanimate individuals. Coetzee, in his works, has repeatedly emphasized the need to respect the individual. In his eyes, the farm belongs only to the farm itself, he said, "in the depths of his heart, he knows and the farm itself also knows: the farm will be greater." The farm moved from one eternity to another. When people died, the farmhouses were deserted, but the farm stood erect on the earth. "The house also has its own charm, the house, the huge, idle, hillside house, with a black passage and a lot of moldy, uninhabited rooms, has its own charm." Everything exists in the universe, material or psychological, which presented in their own unique posture. An embrace with the Other was also an embrace with the Self. No two leaves are the same in the world. That is why the world is so rich and colorful. It is for this reason that Coetzee asks us to respect the individual.

The particularity of the new citizen group is embodied in their lifestyles, the ideology and culture concepts which are affected by the modern civilization of the city. Although they yearn for city life, they are faced with the difficulty of integration in the present environment. At present, in some cities of our country, the term "new citizen" is gradually used to replace the appellation of migrant workers, so that the living conditions of migrant workers and their change during urbanization have aroused widespread concern. Some studies showed that migrant workers who become new citizens have diversified needs for language and writing that can be clearly perceived. Some of these language needs are a kind of 
passive language adaptation for new citizens. They are used to overcome some language difficulties encountered in the process of integration into the city. [13] Our survey shows that $42 \%$ of the new residents think that their living habits are quite different from those of the local people; $39.33 \%$ of the new residents think that the reason for their difficulties in integrating is the conflict of ideas; and a small number of new citizens feel that they are discriminated and cannot feel the city's concern for them. Some new citizens believe that having enough money and spending at the same level as locals can help them integrate better into the city. Many of them think that if they have money, they will be respected by others and make themselves feel like city owners. The survey showed that young people were significantly more easily integrated than other age groups; 48.67 percent said they were fully integrated into urban life. Most young people do not have a family burden, and mostly they live or work for themselves, especially among students. When migrant workers arrive in the city, they speak their home language mixed with mandarin or local dialects. The main influencing factor is the different nature of work. This phenomenon is more common among new citizens in some service industries in which active communication with customers encourages them to keep up with the trend of society. Manual workers, such as those in the construction industry, spend most of their time on construction sites, with little communication to the outside world, thus, there is less influence on their language. As Deleuze says, "When a language is so strained that it starts to stutter, or to murmur or stammer... then language in its entirety reaches the limit that marks the outside and makes it confront silence".[14] As new citizens, they should communicate more with other local people and present others with their own simplicity, which can provide conditions and opportunities for better integration into urban life.

Therefore, the concept of respecting the individual, equality and harmony to serve the identity adaptation of the new citizen is conducive to promoting the integration of different regional cultures, enhancing the understanding between people, and alleviating the personal pressure and social contradictions caused by the difficulties of integration.

\section{Conclusion}

Diaspora has a long history. It has its historical roots and is also affected by political, economic and social development. Diaspora, as a kind of culture, occurs among different cultures. Diaspora literature highlights the cultural interactions between heterogeneous cultures in different cultural situations. [15] With the development of globalization, human mobility has greatly increased, which has brought the collision and integration of different cultures. At the same time, China is in the process of rapid urbanization, the emergence of new citizens has caused cultural exchanges between different regions, and there have been issues of identity and social integration. With the narrative mode reflected in Coetzee's literary works, we can see the importance of the adaptability of language for integration clearly, with the aim to adjust the concept, better carry out social services, and promote the construction of a harmonious society.

\section{Acknowledgements}

Acknowledgments are usually put in the end of the paper, between the reference and the content. There should be no number in this part. This paper was supported by Program for Humanities and Social Science of Heilongjiang Bayi Agricultural University (XRW2017-08).

\section{References}

[1] Said, Edward. "Reflections on Exile", in Reflections on Exile and Other Essays, Harvard University Press, Cambridge, MA, 2003, p. 177.

[2] Li, Xia. Language Urbanization of New Citizens. Journal of Shenyang Normal University (Social Science Edition), No. 5, 2015 Vol. 39 General, pp. 191.

[3] Mei, Xiaoyun. Rootlessness of Culture: An Immigrant Culture Case Study of VS Naipaul. Xi'an: Shanxi People's Publishing House, 2003.

[4] Zhenya, Zhu. An Overview about Research on the Concept and Connotation of "New Citizens". Journal of Huazhong Agricultural University (Social Sciences Edition), No. 118, 2015 Vol. 4, pp. 83. K. Elissa, "Title of paper if known," unpublished.

[5] Attwell, David. Coetzee's Postcolonial Diaspora. Twentieth-Century Literature, 2011, 57 (1), pp 9-19.

[6] Wen Yue, Chen Zhaorong. Diaspora and Marginalization: an Alternative Value Concern of World Literature. Lanzhou: Gansu People's Publishing House, pp 34-35.

[7] Jacobs, J U. Picturing the African Diaspora in Recent Fiction. Current Writing: Text and Reception in Southern Africa. 21: 1-2, pp. 97-116.

[8] Lewis, Pericles. The Cambridge Introduction to Modernism (Cambridge: Cambridge University Press, 2007), p. 11.

[9] Farred, Grant. Out of Context-Thinking Cultural Studies Diasporically. Cultural Study Review, 2009, 3 (15), pp 130-150.

[10] Li, Zhou. Cultural Conflicts in Diaspora Literature: On Coetzee's Biographical Novel Summer. Journal of Liaoning TV \& Radio University, 2018 (04), pp. 44-45.

[11] Qiong, Pang. African Identity or British Identity: Study on Coetzee's Consciousness of Culture Identity in Boyhood and Youth. Proceedings of the International Symposium on Coetze Studies and Postcolonial Literature, 2010.

[12] Fanon, Franz. Black Skin, White Mask. Trans. Wan Bing. Nanjing: Yilin Press, 2005.

[13] Li, Xia. Research on Language Needs of Migrant Workers in the Process of Citizenization. Social Science Journal, No. 6, 2015 Vol. 221 General, pp. 57-61. 
[14] Deleuze, Gilles. "He Stuttered", in Essays Critical and Clinical, trans. Daniel W. Smith and Michael Greco, University of Minnesota Press, Minneapolis, 1997, p. 113.
[15] Shouxiang, Hunag. Maternal Memory and Cultural Integration in the Vision of Diaspora Literature. Hunan Social Science, 2017 (05), pp. 165-172. 